\title{
Dressing and Feeding the Family, or Cakes and Garments for the Gods?
}

In the built environment of a past society it is often difficult to distinguish between sacred and profane objects and places. We struggle with the difficult tasks of recovering and understanding the behaviours that took place in domestic and public units.

Baking, spinning and weaving can be traced very well in the archaeological record from artifacts such as ovens, spindle whorls, loom weights and other remnants representing a loom. Traces of weaving and baking are often found in domestic context. Weaving and baking for a temple and especially weaving clothes and backing bread for a deity are well-known phenomena in the ancient Near East. But in the archaeology of the Southern Levant weaving and baking in association with a temple or a shrine seems to be overlooked.

Khirbet al Mudayna, Tell Deir Alla and Tell es-Saidiyeh, situated in Transjordan, with their huge and concentrated numbers of Iron Age loom weights and distinctive architecture, indicate production for others than the direct inhabitants, suggesting specialization and trade. But who were these others. By comparing the features of the three sites an answer to the above question can be indicated. 